\title{
AIRPORT-AIRLINE RELATIONSHIPS: OPPORTUNITIES FOR ITALIAN REGIONAL AIRPORTS
}

\author{
S. CEPOLINA ${ }^{1} \&$ G. PROFUMO ${ }^{2}$ \\ ${ }^{1}$ Italian Centre of Excellence on Integrated Logistics (CIELI), University of Genoa, Italy. \\ ${ }^{2}$ Department of Business Studies, University of Naples "Parthenope", Italy.
}

\begin{abstract}
In recent years, the aviation industry is facing fast evolution patterns and strong competition in its main sectors. On the one hand, the increasing competition between airlines is lowering industry profitability. On the other hand, airports are facing new managerial challenges due to privatisation processes. Not only international airports but regional airports also are affected by these phenomena. This turbulent environment is pushing companies in the aviation industry to follow new strategic paths in order to face the new competitive arena; one of the paths that is gaining increasing attention is cooperative strategy, created in order to reduce uncertainty, sharing risks and costs. The literature has primarily focused its attention on horizontal alliances, while less attention has been given to vertical integration strategies between airports and airlines. The aim of the present work is, therefore, to cover this literature gap, analysing the airport-airline relationships from a strategic management perspective. After a brief classification of all the possible forms of relationship, the potential benefits for the two actors, airlines and airports, will be analysed, trying to underline the possible cost and revenue synergies. Particular attention will be given to regional airports, some of which are now experiencing fast development, due to the interaction with airline companies. This is the case of the two Italian regional airports investigated in the second part of the paper.
\end{abstract}

Keywords: airport-airline interaction, regional airports, vertical integration strategy.

\section{INTRODUCTION}

In the last few years, the aviation industry has been affected by external events and developments, such as globalisation and liberalisation/deregulation processes, that have challenged all the actors belonging to the value system, with special reference to airports and airlines. On the one hand, the increasing competition between airlines, boosted by the entry of low cost carriers (LCCs) in the market, is squeezing companies to a price war, diminishing industry profitability. On the other hand, airports are experiencing, because of the privatisation processes, managerial challenges which, in some cases, still have to be matched with political objectives. This is the case of regional airports, a large part of which is still public owned.

As the environment is becoming more and more turbulent, companies operating in the aviation industry are seeking strategic paths in order to survive in the new competitive arena. Growth strategies, in particular, may enable firms to face high competition levels, maintaining a sufficient profitability, reaching economies of scale and scope and holding higher bargaining power, but to be effective, in an uncertain and very dynamic framework, the implementation process has to be fast. Internal expansion, known also as organic growth, may not be suitable, because it is usually a slow process that requires large financial resources. So, the resources and competences needed for the expansion should be found in other firms, through different forms of relationship that range from simple agreements to mergers and acquisitions (external growth strategies).

In recent years, the literature has extensively focused on horizontal alliances and mergers and acquisitions (M\&A) processes inside many industries of the air transport value system, while less attention has been given to vertical integration strategies between airports and airlines in particular. Aiming at covering this literature gap, the present work explores airport-airline relationships from a strategic management perspective.

Airports and airlines are very different subjects with a separate regulation regime, diverse competitive arenas, not similar strategic behaviours, but, at the same time, they are linked by a customer-supplier 
relationship and they serve the same final customers, passengers [1]. These aspects, together with recent airport-airline interaction experiences, like Lufthansa's cooperation with German airports of Frankfurt and Munich, require a deeper analysis of airport-airline forms of interaction.

Moving from these considerations, the present paper focuses on airport-airline relationships in the Italian aviation industry.

The Italian case is rather peculiar, at least for two reasons. Firstly, the network of national regional airports is highly spread, with many small airports characterised by different growth rates and there is a lack of a strong flag carrier. Secondly, the Italian regulatory framework, with its particular 'concession regime', still has a very strong influence on airport operations and the development of any relationship with airlines. Moreover, the Italian aviation market is the fifth largest European market in terms of passengers, with 135 million passengers in 2007, and it has recorded an average annual growth rate of $8.2 \%$ in the last 5 years, consistently higher than other more developed markets [2].

The paper is structured as follows. Section 2 shows managerial literature on the different forms of relationships between firms using corporate control as the lens of analysis and focuses attention on the literature contributions related to airport-airline interactions. This part of literature is less developed and there are still comprehension and behavioural gaps to overlap. Section 3 is aimed at identifying the drivers that may push airlines and airports to engage vertical integration strategies through different external implementation processes. Section 4 presents an up to date portrait of the Italian aviation industry, focused on the principal characteristics of the airport system and the airlines operating in the national area. Section 5 tries to verify the drivers of vertical integration strategies in two selected case studies of Italian regional airports. Finally, Section 6 concludes with a brief discussion of results and possible future fields of research. Although the paper is the outcome of a collective work, Paragraphs 1; 2.2; 4 and 5.2 can be attributed to S. Cepolina, while Paragraph $2.1 ; 3 ; 5.1$ and 6 can be attributed to G. Profumo.

\section{AIRPORT-AIRLINE VERTICAL FORMS OF INTERACTION}

The managerial literature on firms' relationships is really deep and rich, following different lens of analysis. In this section, the approach based on corporate control will be used in order to evaluate the specificities of the airport-airline vertical forms of interactions.

In the aviation industry, literature has extensively focused on firms' relationships inside each sector (e.g. airline's alliances and M\&A, aircraft constructors' concentration processes), while less attention has been given to the study of vertical forms of interaction between companies belonging to different stages of the value system.

\subsection{Managerial literature on firms' relationships}

Following their corporate strategies, firms may choose to grow by enhancing the resources and competences that are internally generated (organic growth) or by utilising and developing resources, knowledge and capabilities available in other companies. This second implementation process may take several forms, depending on the business relationship developed between the two firms.

The existing managerial literature has elaborated different taxonomies of the phenomena. For the purpose of our paper, it is useful to classify business relationships according to the type of corporate control; following this classification, they can range in a spectrum that goes from a simple, shortterm transactional relationship to a full acquisition or merger, in which a company takes the entire ownership of another [3], as indicated in Fig. 1. Moving towards M\&A implies, on the one hand, a continuous increase in the commitment of the companies involved in the relationship to achieve the foreseen objectives and a greater steadiness of the interaction; on the other hand, a higher business risk, due to the greater investment and the difficulty to exit from the relationship. 


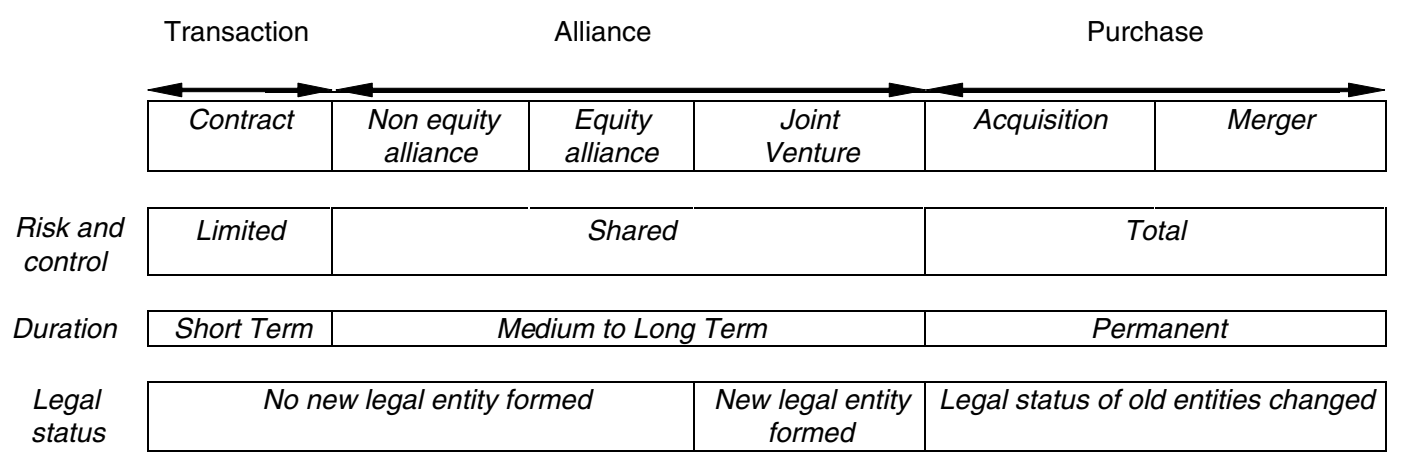

Figure 1: The spectrum of business relationships. Source: Adapted from Ref. [3].

In the case of a transactional relationship, as for example the interaction between a customer and its supplier, one company may, to some degree, influence the other firm, but the control is limited in scope (only to what is written in the contract) and duration. As the partners usually do not invest too many efforts, in terms of resources and competences, in this short-term relationship, their business risk is also limited.

The different forms of alliance fall in the middle of the spectrum. They can be defined as inter-firm relationships in which two or more companies jointly invest in a common activity over a number of years, sharing risks and returns, but remaining legally independent. Only in the case of a joint venture there is the creation of a new legal entity.

The term 'strategic alliance' includes a wide range of relationships that vary from long-term purchasing agreements to marketing and research and development (R\&D) collaborations, to joint ventures $[4,5]$. Despite the differences, all the alliance forms present at least a few common features [4]: the link between the alliance's scope and the strategic intent of each partner [6], the sharing of resources and knowledge among partners [7] and the creation of opportunities for organisational learning [8].

Alliances are more complex to manage than transactional relationships and usually have a longer lifetime, even if they have a clear endpoint. They are very useful in uncertain and risky market conditions, as they limit the resources a company must commit to the new venture [3]; they are, indeed, often viewed as a mechanism to cope with uncertainty.

In some forms of alliance, the companies reciprocally purchase minority equity stakes in order to maximise the commitment to the joint project, this is the case of equity alliances.

Because partners in an alliance remain independent, a single partner is not able to control the others completely and there is the multiplication of decision-making centres, which implies longer and more complex decisions on controversial issues, such as eliminating redundant assets, rationalising product lines or specialising facilities. Alliances are also transient in nature; they can be closed without too many difficulties. For these reasons, alliances are less effective when there is economic value to be gained through rationalisation, which implies cost cutting: 'horizontal acquisition will always outperform scale alliances' [9].

On the other side of the spectrum, we can find M\&A, in which the control on the other company is permanent and complete. In a merger, the level of integration between firms is maximum, as the companies become one new expanded legal entity, such an instrument is very complex to manage [10], as it implies the full blend of managers, staffs, competences and values. In an acquisition, a firm takes an ownership stake in another company, sufficient to exercise the control; in this case, the integration process may be absent or focused on specific functions, such as information and technology (IT) or R\&D.

The full ownership control presents some specificities: on the one hand, a company has to invest resources, knowledge and to assume the responsibility for the acquired assets, increasing its business 
risk. So, if the market conditions are already very risky and uncertain, a company should choose other forms of relationships. On the other hand, the full corporate control allows the company to better achieve tough decisions much more rapidly than in case of alliances, in which the decision process may be blocked by the intervention of many actors [9].

\subsection{Airport-airline interactions literature}

Airport-airline interactions are frequent only in few parts of the world, e.g. Asia, Australia and Arab nations, where airport operators and airlines are part of the same group and share the mission to support each other for the sake of the country's competitiveness and economic development [11]. This consideration supports the limited amount of research and only recent developments in this field.

Over the last decade, however, airport-airline interactions have gained increasing attention in US and Europe also, where they are seen as a strategic answer to the straightening competition in the aviation industry and to the privatisation process that characterises the entire aviation industry.

On the one hand, airlines are squeezed among their neighbours in the aviation value system that leverages local monopolies (such as airports) or oligopolies (such as aircraft equipment manufacturers) [12]. Despite ongoing liberalisation, the regulatory framework still has not reached a common European level, to be able to push consolidation processes in the aviation industry. Airport price regulation forms are particularly relevant and there are strong differences in their stage of adoption among European countries [13, 14].

On the other hand, airports across the world are modifying their business model, focusing more and more on non-aeronautical revenues (retailing, advertisement, ground transport and property development) to generate financial resources. In the case of hub airports, resources are designated to increase capacity to meet infrastructure demands; in the case of secondary airports, resources are designated to increase airport attractiveness and to gain air traffic [15].

Secondary airports management often has an additional critical point to face because of the local public ownership, which seeks to balance economic aims (profit maximisation) with political and social aims (occupation, local well-being). The top management needs to reach remarkable levels of air traffic with a limited bargain power. Under these conditions, the strategy of secondary airports is to look more and more to LCCs as partners, because of their traffic generating ability.

Since these new competitive matters are gaining more and more relevance, researchers have started to highlight them and literature has been developed. The emerging literature on airport-airline relationships may be classified into two big categories.

The first category is based on the different aims of the agreement between airlines and airports. These types of classifications are numerous and are generally articulated in air service agreements and land service agreements. The first tends to develop new traffic and is devoted to airports with overcapacity status, like numerous European secondary airports. The second, however, tends to improve efficiency to better utilise existing capacity. They are devoted to highly congested airports, like European hub airports.

In this category, some authors $[16,17]$ identify three agreement levels: marketing oriented (called land services), capacity oriented (called air side services) and security/technology oriented.

The first two levels are strongly strategic, aiming at growth of airports and airlines; security/ technology oriented collaborations are instead more operational, aiming at increasing performance. They usually tend to improve airport security level as well as process efficiency (baggage processing technology) and they do not need a long-term relationship.

The second literature category is based on the characteristics of the relationship, like time coverage, steadiness and actors' commitment. This category originates from general managerial relationships 
literature, modified in order to fit aviation industry specificities. Different interaction forms are identified on the basis of the classification highlighted in Fig. 1: cooperation agreements, alliances, joint ventures and M\&A $[18,19]$. Many recent aviation industry phenomena can be observed through this lens of analysis; long-term usage contracts between airlines and airports as cooperation agreements, signatory airlines as a form of alliance, joint ventures and acquisitions.

We also include in this second category the studies which analyse airport-airline interactions on the basis of the different kinds of subjects involved, like the copious contributions focused on LCC and secondary airport interactions $[1,20]$.

\section{AIRPORT-AIRLINE INTERACTION DRIVERS}

The existing literature on the determinants of the different forms of business relationships is wide and rich, even if fragmented. There are several studies focused on each type of relationship, in particular, on the motivations of alliances and M\&A, but less attention has been given to create a common framework from which arise the drivers that may push firms to expand using the resources and competences present in other companies.

Related research has shown that the determinants of M\&A and alliances, associated with the maximising of a firm's value, are quite similar and may be broadly categorised into [21-23] efficiency or operational drivers and market power drivers. The former synergies are related to economies of scale and scope and all the other cost economies that may be achieved by larger firms; the latter synergies, however, emerge from the possibility to access or create new markets or 'strategic windows', to develop knowledge and capabilities that are not present in the firm, and from the ability of the partners to control the price, the quantity or the nature of the products sold, thereby generating extra-normal profits (collusive synergies) [22]. The process of value creation may also involve taking strategic actions related to financial and risk diversification, in particular, in case of M\&A [24, 25]. Alliances are the only form of external expansion that can be used in case of legislative barriers of entry (in the airline business, for example, as the regulatory framework strictly prohibits cross-border mergers, alliances represent the only instrument that allows airlines to serve the global market).

The business relationship drivers have been extensively studied inside each stage of the aviation value system, in particular, in the case of alliances and M\&A among airlines [26-30], less attention has been given to understand the motivations of vertical integration strategies. This literature is, in fact, more recent and it is mainly focused on case study analysis [17, 31-34].

The few studies related to the vertical forms of interaction between airports and airlines highlight that, although the relationship's final attempt is to jointly serve customers and cope with traffic demand in a profitable, efficient and sustainable way [17], there are specific drivers for airports and airlines that push them to interact. The relationship is goal oriented; both parties enter into it for their own benefit [11]. The airport-airline interaction has also changed in nature in the last few years, passing from a pure transactional 'supplier-customer' relationship to a more strategic agreement.

Our attempt is to identify the drivers that may push airlines and airports to engage in vertical integration strategies through different external implementation processes and, then, to verify them in two case studies belonging to the Italian aviation industry.

Following the drivers emerging from the general literature, airport-airline interaction drivers may be distinguished into efficiency driven and market power driven. Inside each category, it is then possible to identify specific drivers for airports and airlines, as summarised in Table 1.

The efficiency drivers are in both cases related to the cost economies that may be achieved through the interaction. As regards airports, the increasing traffic emerging from the relationship with an airline helps them to enhance operational capacity and consequently reduce unit costs; studies have 
Table 1: Airport-airline interaction drivers.

\begin{tabular}{lcl}
\hline Interaction category & \multicolumn{1}{c}{ Airlines drivers } & \multicolumn{1}{c}{ Airports drivers } \\
\hline Efficiency/operational drivers & $\begin{array}{c}\text { Cost economies, risk sharing, } \\
\text { higher service quality } \\
\text { Market power/strategic drivers } \\
\text { Create a strong hub, create a } \\
\text { feeding traffic to the hub, } \\
\text { control of airport slots, develop } \\
\text { traffic in the basin of the airport, } \\
\text { better image }\end{array}$ & $\begin{array}{c}\text { Cost economies, risk sharing, } \\
\text { higher service quality } \\
\text { Improved connectivity, increasing } \\
\text { bargaining power, longer } \\
\text { term planning, regional social } \\
\text { benefits, better image, increasing } \\
\text { non-aviation revenues }\end{array}$ \\
\hline
\end{tabular}

Source: Our elaboration.

in fact demonstrated that unit costs decrease significantly as traffic increases up to 1.5 million work load units (WLU - defined as one passenger or $100 \mathrm{~kg}$ of freight) per annum and continue to fall until traffic reaches 3.0 million WLUs per annum [13]. As regards airlines, cost economies may arise, besides from traffic development, from a large set of activities undertaken by airports, called air service development [16]. Many airports, in fact, especially regional airports with low bargaining power, are now taking a share of the costs (and of the risks) of developing airline networks, providing services traditionally under the responsibility of airlines, such as analysis of the potential demand for a particular route, marketing activities for the development of the route traffic, financial incentives and handling cost reductions.

The operational drivers are also related to the increase in service quality, due to more customised services and due to the development of operational airport capacity by joint management of on time performance [16]. However, one of the primary drivers for the formation of relationships between airports and airlines is the reduction of risk and uncertainty for both parties [17], obtained through the sharing of investment costs.

The market power drivers are related to the acquisition of 'revenue' synergies, linked to the development of traffic and the preference of consumers. From an airline's point of view, a strong interaction with an airport may be driven by the will to create a feeding traffic towards its primary hub, to set up a strong hub and to control airport slots (in particular in already congested airports), in order to offer customers seamless connections and gaining their preference. However, in case of M\&A, some anticompetitive effects have been highlighted [32], such as decreasing quality for rival airlines, discrimination in the access to ground handling services and predatory practices towards competing airlines using cross-subsidies.

From an airport's point of view, the market power/strategic drivers are, instead, related to: the increase in its accessibility and connectivity; the possibility to plan with a longer term; the development of traffic in the airport basin, with social benefits for the region; and the increase in non-aeronautical revenues.

In both cases, there could also be an improvement in the image and reputation of the partners that in some cases may profit from the standing of each other.

\section{ITALIAN AVIATION INDUSTRY: LEGISLATIVE FRAMEWORK AND SPECIFICITIES}

The Italian airline sector is one of the most attractive markets in the European panorama. Its weight in terms of passenger traffic is relatively small $(11.88 \%$ of the EU total pax traffic based on OAG data), but it is destined to increase consistently in the next years. 
The evolution trend for past traffic, with strong growth rates, in particular in the domestic sector, highlights the relative newness of the Italian market where the propensity to fly is still lower than the European average. As a young market, Italy is also a very dynamic market, characterised by legislative openness and a consequent high level of competition. Italian market competitiveness is also affected by the low market share hold by the Italian national flag carrier, Alitalia, which in 2006 was $25 \%$, compared to the $45 \%$ hold by Air France in France.

Moreover, in 2006 the Alitalia crisis emerged, resulting in a period of decline that ended only in 2008. In that year, a new company, Cai-Alitalia, was constituted with the purpose of integrating Alitalia and AirOne, the two most important Italian flying carriers, by acquiring their main assets. This event had strong traffic implications: comparing the data for the last 2 years (2007-2008), Alitalia has seen a fall of $26 \%$ in passengers carried (from 24.4 to 18 million); the nearly 6.5 million passengers who have abandoned Alitalia have not just moved to AirOne, whose clients have increased only from 7.1 to 7.4 million, but went elsewhere. So, by combining the two companies, there is a fall from 31.5 million passengers in 2007 to 25.5 in 2008.

A last consideration refers to LCCs, which account for $29.9 \%$ of national supply (available seat kilometres) in 2008, with an annual growth rate of 48.5\% in the period 2001-2008 (based on OAG source). In this business model there is no competitive national player (the first Italian LCC, Myair, with a market share of just $6 \%$, is now close to bankruptcy) and the great majority of the growth is imputable to foreign LCCs (Ryanair and Easyjet, in particular, have a market share, respectively, of 32.6\% and 17.5\%).

As regards the Italian airport sector, the market is composed of 101 airports. Among them, 45 are classified by the Italian regulatory authority ENAC as international (they can schedule international flights) while the remaining 56 are labelled as domestic (they can schedule only domestic flights) [35].

The framework highlights a widespread dissemination of Italian airports, which is confirmed by air traffic statistics. Table 2 shows a low level of air traffic concentration, which has decreased from 2000 to 2007.

Concentration levels are calculated for different airports classes, including airports with the highest passenger traffic. The first two classes (top 5 and top 10 Italian airports) have lost much more traffic, in the time gap considered, than the other classes (top 20 and top 30 Italian airports). This trend may be explained by the more intense growth of Italian secondary airports supported by the advent of LCCs and by the increasing weakness of the national flag carrier.

The development of secondary airports may be better appreciated by looking at Table 3, which shows total growth rate between 2000 and 2007 for different classes of Italian airports. In this case, airport classes are identified on the basis of the passenger traffic related to year 2000. The total growth rates are indirectly related to the airports' dimensions in terms of passengers: smaller airports have grown more than their bigger counterparts.

Table 2: Italian air traffic concentration.

\begin{tabular}{lcccc}
\hline Airports & Pax 2000 & $\begin{array}{c}\text { Concentration } \\
\% 2000\end{array}$ & Pax 2007 & $\begin{array}{c}\text { Concentration } \\
\% 2007\end{array}$ \\
\hline First 5 & $60,471,235$ & 66.14 & $79,200,150$ & 58.53 \\
First 10 & $76,261,828$ & 83.41 & $104,769,202$ & 77.43 \\
First 20 & $87,947,712$ & 96.19 & $128,360,982$ & 94.86 \\
First 30 & $91,056,923$ & 99.59 & $134,406,226$ & 99.33 \\
Total & $91,434,374$ & & $135,315,674$ & \\
\hline
\end{tabular}

Source: Our elaboration on ENAC data. 
Table 3: Total growth rate in different Italian airports' classes (2000-2007).

\begin{tabular}{lrrrr}
\hline Airports & Pax 2000 & \multicolumn{1}{c}{ Pax 2007 } & \multicolumn{1}{c}{$\Delta 07-00$} & \multicolumn{1}{c}{$\Delta 07-00 \%$} \\
\hline$<1,000$ pax & $5,710,300$ & $11,242,147$ & $5,531,847$ & 96.87 \\
$1,000-2,000$ pax & $7,425,291$ & $15,594,506$ & $8,169,215$ & 110.02 \\
$2,000-3,000$ pax & $7,202,153$ & $12,448,595$ & $5,246,442$ & 72.85 \\
3,000-5,000 pax & $18,699,558$ & $29,908,252$ & $11,208,694$ & 59.94 \\
$>5,000$ pax & $52,397,072$ & $66,121,388$ & $13,724,316$ & 26.19 \\
Total & $91,434,374$ & $135,315,674$ & $43,881,300$ & 47.99 \\
\hline
\end{tabular}

Source: Our elaboration on ENAC data.

A second Italian aviation industry specificity relates to airport governance. The great majority of Italian airports are managed by independent companies through a license delivered by the Italian regulatory authority (ENAC) (only 2 airports of the 45 international airports are public managed directly by ENAC).

Licenses can be distinguished into total licenses and partial licenses. With the former, managing companies are responsible for the airport infrastructures and get all the airport's charges; in the case of the latter, managing companies are responsible only for passenger and freight infrastructures (like terminals) and get only related charges. There is a third license category called precarious, similar to partial license with reference to infrastructures provision: in this case, managing companies obtain revenues only from terminal commercial activities (no collection of charges is foreseen) [36].

We have analysed airport governance with reference to airports with more than 1 million pax in 2007 (see Table 4) by classifying shareholders into two main categories: public and private subjects, of which the latter is split into airport management companies, airlines and a residual category.

The resulting sample, which includes 34 airports, shows an advanced stadium of the privatisation process, formally started in 1993 (with Italian law n. 537/1993 and Italian law n. 351/1995), although public influence is still very strong. In fact, most of the airports (21) are controlled by public local authorities, like regional administrations and municipalities. Two airports are directly managed by ENAC and the remaining airports (11) are owned by private subjects. There are, however, very few cases in which airlines participate in airports' capital. From these observations, it is clear that airlines prefer soft forms of relationships, like transactional relationships and alliances.

In order to complete this scenario of the Italian airports sector we introduce some information on airport charge national regulation. In 2005, the Italian Government approved a new law (n. 248/2008) changing the framework for setting airport's charges. The new policy set up a price cap hybrid till (allowing costs netted of 50\% of commercial margin), abolishing any pre-existing alignment of Italian airport charges with the rest of Europe. As a consequence, the charges for Italian airports are now lower than the European average, in a range between $19 \%$ and $49 \%$, depending on different variables [37].

The Italian association of airports (Assaeroporti), as well as ACI Europe, at the European level [38], states that the present average return on capital of airports is very low and might not be acceptable for the private sector, in order to sustain the necessary investments to maintain, upgrade or expand the long-term tangible assets of airports, such as terminals, runways, access roads and car parks, as well as to expand the capacity in order to follow a growing demand. 
Table 4: Italian airports classified by shareholders' categories.

\begin{tabular}{|c|c|c|c|c|c|c|}
\hline & \multicolumn{5}{|c|}{ Shareholders category } \\
\hline & & \multicolumn{3}{|c|}{ Private } & \multirow{2}{*}{ 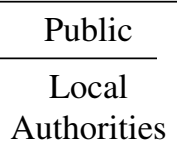 } & \multirow[b]{2}{*}{ ENAC } \\
\hline & Airport & $\begin{array}{l}\text { Airport management } \\
\text { companies }\end{array}$ & Airlines & $\begin{array}{l}\text { Other private } \\
\text { subjects }\end{array}$ & & \\
\hline 1 & Alghero & & & & $100 \%$ & \\
\hline 2 & Ancona & & & & $>90 \%$ & \\
\hline 3 & Bari & & & & $100 \%$ & \\
\hline 4 & Bergamo & $30 \%$ & & $30 \%$ & $40 \%$ & \\
\hline 5 & Bologna & $<10 \%$ & & $<5 \%$ & $>85 \%$ & \\
\hline 6 & Brescia & $85 \%$ & & & $15 \%$ & \\
\hline 7 & Brindisi & & & & $100 \%$ & \\
\hline 8 & Cagliari & $<0,5 \%$ & & $<2 \%$ & $>97 \%$ & \\
\hline 9 & Catania & & & & $100 \%$ & \\
\hline 10 & Crotone & $>50 \%$ & & $>5 \%$ & $<40 \%$ & \\
\hline 11 & Firenze & $>33 \%$ & $<20 \%$ & $<20 \%$ & $>30 \%$ & \\
\hline 12 & Forlì & & & & $100 \%$ & \\
\hline 13 & Genova & $10 \%$ & & & $90 \%$ & \\
\hline 14 & Lamezia Terme & $15 \%$ & $<20 \%$ & & $>67 \%$ & \\
\hline 15 & Lampedusa & & & & & $100 \%$ \\
\hline 16 & Napoli & $65 \%$ & $5 \%$ & $5 \%$ & $25 \%$ & \\
\hline 17 & Olbia & & $<80 \%$ & & $>20 \%$ & \\
\hline 18 & Milano Malpensa & & & $>5 \%$ & $>95 \%$ & \\
\hline 19 & Milano Linate & & & $>5 \%$ & $>95 \%$ & \\
\hline 20 & Palermo & & & & $100 \%$ & \\
\hline 21 & Pantelleria & & & & & $100 \%$ \\
\hline 22 & Parma & $<67 \%$ & & $>10 \%$ & $>20 \%$ & \\
\hline 23 & Pescara & & & $>5 \%$ & $>95 \%$ & \\
\hline 24 & Pisa & $2 \%$ & & $<48 \%$ & $>50 \%$ & \\
\hline 25 & Reggio Calabria & & & & $100 \%$ & \\
\hline 26 & Rimini & & & & $>80 \%$ & \\
\hline 27 & Roma Ciampino & & & $>95 \%$ & $<5 \%$ & \\
\hline 28 & Roma Fiumicino & & & $>95 \%$ & $<5 \%$ & \\
\hline 29 & Torino & $>5 \%$ & & $>44 \%$ & $51 \%$ & \\
\hline 30 & Trapani & $>4 \%$ & & $<42 \%$ & $54 \%$ & \\
\hline 31 & Treviso & $80 \%$ & & $<2 \%$ & $>18 \%$ & \\
\hline 32 & Trieste & & & & $100 \%$ & \\
\hline 33 & Venezia & & & $>50 \%$ & $>33 \%$ & \\
\hline 34 & Verona & & & $>10 \%$ & $>90 \%$ & \\
\hline
\end{tabular}

Source: Our elaboration on AIDA data and company websites.

To meet these requirements the European Commission has recently prepared a directive (2009/12/ CE of March 11, 2009), which establishes a general framework, setting common principles for the levying. Sharing the aim of the community legislator, we stress the narrowness of its application, limited to airports with more than 5 million passengers. In Italy, the directive could be applicable in only eight airports, which account for $70 \%$ of the total national traffic. 


\section{AIRPORT-AIRLINE INTERACTION DRIVERS: LESSONS FROM ITALIAN EXPERIENCES}

In order to verify the airport-airline interaction drivers identified in Section 3, we have selected two case studies, both regarding regional airports, emerging from the Italian airport sector.

The first case, Olbia Airport in Sardinia Island, with 1,741,120 passengers in 2007, is the only Italian case of an airport management company (Geasar S.p.A.) controlled by an airline, Meridiana, a regional carrier which holds $79.79 \%$ of Geasar shares.

The second case, Genoa Airport, with 1,105,802 passengers in 2007, is a regional airport facing very high competition. In the same catchment area, in fact, at a distance lower than $200 \mathrm{~km}$, there are five international airports: Nice (France), Turin, Milan Linate, Milan Malpensa and Pisa. In order to improve its competitive position, Genoa Airport has developed relationships with many carriers of different nature.

\subsection{Case study A: Olbia Airport}

Olbia Airport is a regional airport located on the northeastern coast of Sardinia Island, with a prevalence of tourist traffic. The airport management company Geasar S.p.A. represents a rather peculiar case in the Italian airport sector, as at the moment it is the only one controlled by an airline company. Meridiana Airlines, in fact, holds the majority of its shares (79.79\%), whereas few public regional authorities are minority shareholders: Sassari Chamber of Commerce (with a share of $10 \%$ ), Nuoro Chamber of Commerce (with a share of 8\%), Sardinia Region Administration (with a share of 2\%) and Emerald Coast Consortium (with a share of 0.2\%).

Olbia Airport started its operations in 1974, by substituting the former airport of Venafiorita, and was managed (with a partial license) by Geasar S.p.A since March 1989. In 2005, the company obtained the total license to manage the airport for 40 years.

Meridiana Airlines, the principal shareholder of the airport management company, is a regional carrier established in March 1963, with the name Alisarda, by Prince Aga Khan. The carrier started its operations as an air taxi and charter operator, holding the objective of favouring the development of the tourist industry in the Emerald Coast, which until then was accessible only by sea. In 1966, the airline started to serve Rome and Milan from Olbia; in the following 2 years, it opened other national routes. In 1991, the carrier changed its name to Meridiana, following the shareholders' agreement on the fact that the airline's future was the pan-European market and it entered the European market with new international routes (Barcelona, Paris, London and Frankfurt).

In December 2006, Meridiana acquired a 29.95\% stake in the growing leisure carrier Eurofly, through the acquisition of 4 million shares from Spinnaker. In 2008, the carrier increased its stake in Eurofly to $46.1 \%$ of the shares.

The ownership of Meridiana Airlines is held directly and indirectly by Aga Khan, with a majority stake (79.29\% of shares), while the company's employees and a bank foundation (Fondazione Cariplo) represent the other principal minority shareholders.

The acquisition process of the Olbia Airport may be explained by the will of the airline to contribute to the development of tourism (and of the traffic) in the area, increasing regional social benefits. Prince Aga Khan is, in fact, the founder of the Emerald Coast Consortium, whose primary objective is the creation of an integrated tourist value system. The diversification strategy that the carrier has followed in the last few years may be read in the same way: in June 2006, in fact, Meridiana launched Wokita.com, the company's on-line tour operator. Wokita's ambition is to offer tourist booking services (hotels, car rentals, flights, holiday deals) on all the destinations served by Meridiana. Then, in September 2006, the carrier acquired 15\% of the shares of ADF, the management company of Florence Airport. 
The other airline's drivers of the acquisition process may be related to the customisation of services, cost sharing and the possibility to create a base in the airport, also with maintenance infrastructures.

The airport's drivers are firstly related to the development of passenger traffic and the improvement of connectivity. The expansion of the airport has been strictly associated with the development of Meridiana Airlines which, obviously, is the dominant carrier, with $56.9 \%$ of the traffic held in 2007. The rest of the traffic is generated by LCCs, which account for $33.4 \%$ of the total passenger traffic [39] and other charter operators; traditional carriers are almost absent. The airline business models serving Olbia Airport are perfectly coherent with the characteristics of passenger traffic, i.e. seasonal and primarily related to tourism (as the prevalent north versus south traffic highlighted by the route map in Fig. 2 shows).

Starting from 1989, the year in which Geasar S.p.A. began its activities, the airport traffic has continuously grown at an average rate of 5\% per annum, reaching 1.5 million passengers in 2003 (in the same year the annual growth rate was $12 \%$ ). This passenger traffic increase, emerging mostly from the relationship with Meridiana Airlines, has helped the airport to enhance its operational capacity and consequently reduce unit costs. The sharing of risk and investment costs has been another important motivation for the airport. In 2004, for example, the process of renovation and expansion of the airport infrastructures was completed, with an investment of 46 million Euros. Part of this investment was also related to the creation of a commercial area for developing non-aeronautical revenues, according to the new airport's commercial business model.

All the drivers mentioned before are summarised in Table 5.

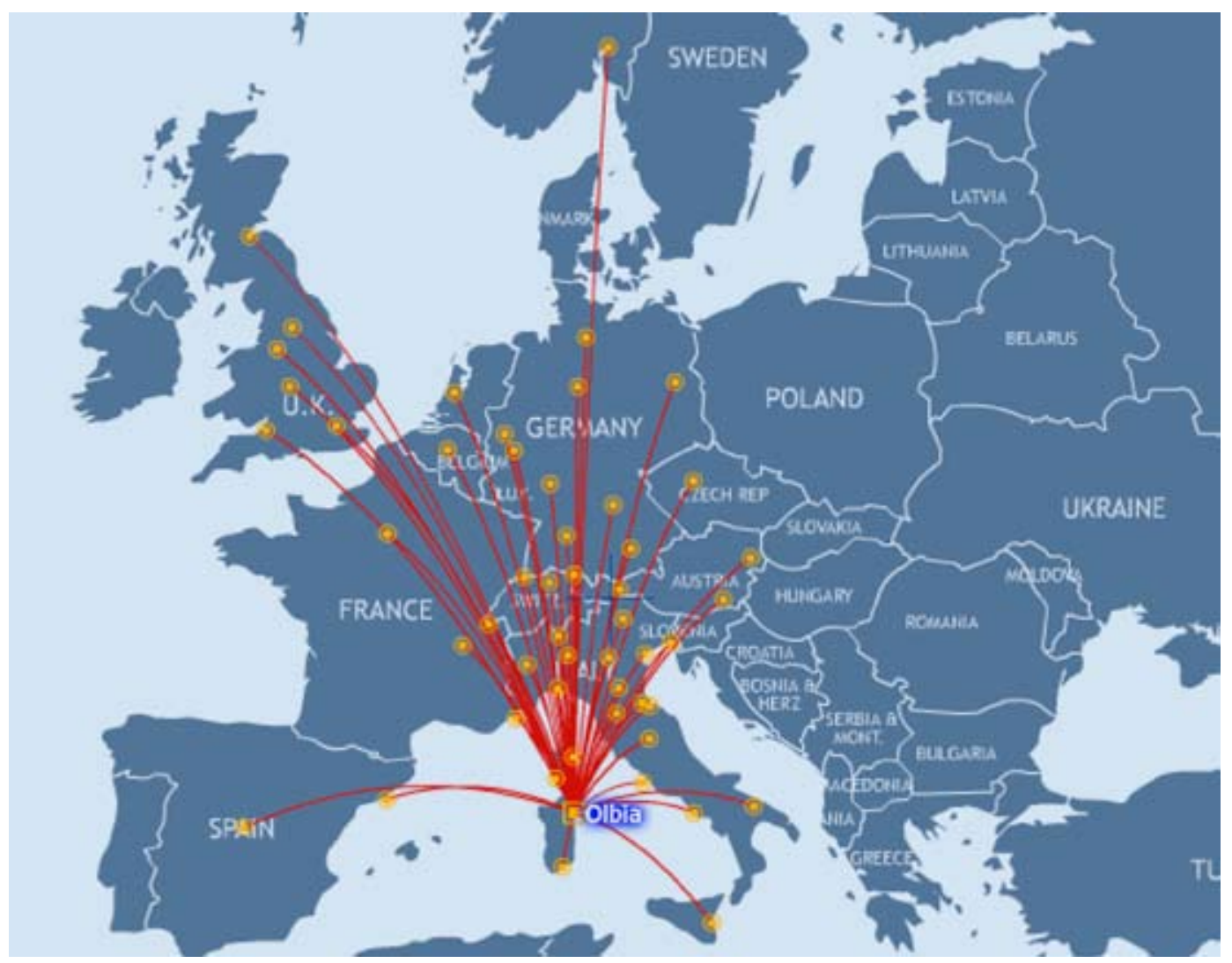

Figure 2: Olbia Airport route map. Source: www.rati.com. 
Table 5: Olbia Airport -airline interaction drivers.

\begin{tabular}{lll}
\hline Interaction category & \multicolumn{1}{c}{ Airlines drivers } & \multicolumn{1}{c}{ Airports drivers } \\
\hline $\begin{array}{l}\text { Efficiency/ } \\
\text { operational drivers }\end{array}$ & $\begin{array}{l}\text { Cost and risk sharing (maintenance } \\
\text { infrastructures), customised } \\
\text { services }\end{array}$ & $\begin{array}{c}\text { Risk and cost sharing (airport } \\
\text { expansion investment; declining } \\
\text { unit costs), higher service quality } \\
\text { (increased operational capacity) }\end{array}$ \\
$\begin{array}{l}\text { Market power/ } \\
\text { strategic drivers }\end{array}$ & $\begin{array}{l}\text { Create a strong hub (Olbia is } \\
\text { Meridiana hub), control of airport } \\
\text { slots (Meridiana is the main shareholder } \\
\text { of the airport management company), } \\
\text { regional social benefits }\end{array}$ & $\begin{array}{l}\text { (development pax traffic), } \\
\text { regional social benefits (tourism } \\
\text { development), increasing } \\
\text { non-aviation revenues } \\
\text { (new commercial area) }\end{array}$ \\
\hline
\end{tabular}

Source: Our elaboration.

\subsection{Case study B: Genoa Airport}

Genoa is a regional airport located on the northwest coast of Italy, which is public held (Genoa Port Authority $60 \%$, Genoa Chamber of Commerce 25\% and Roma Airport Management Company $15 \%$ ). Genoa Airport is facing strong competition from five other airports which serve the same catchment area (the number of people living within the area in which Genoa Airport is reachable in approximately 2 hours of transport, i.e. less than 2 million people). This specificity, together with the absence of a focalisation strategy, explains Genoa Airport's traffic trend, which shows a slower growth rate than its counterparts.

In order to improve its competitive position, the management company has started, in the last few years, to invest in a growth strategy based on different types of interaction with airlines. The final goal is to increase passenger traffic through higher connectivity (in fact Fig. 3 shows a limited number of routes) and market diversification. In this way, the airport has intensified its relational network with different types of subjects, which can be classified into traditional carrier, charter carrier and LCC. Interaction drivers between Genoa Airport and different airline's categories are next investigated and summarised in Table 6.

The five traditional carriers that operate at the moment at Genoa Airport (Cai-Alitalia, Air France, Lufthansa, Iberia and British Airways) represent the great majority of airport traffic. Cai-Alitalia, in particular, accounts for almost $50 \%$ of passenger traffic, operating as the dominant carrier.

The airport strategy towards this typology of carriers is focused on strengthening the company's bargaining power by trying to decrease the dependence on the dominant carrier. In order to achieve this objective, Genoa Airport is building relationships with other traditional carriers. These types of relationship, mainly transactional based, are guided by the following airport's drivers: promoting the region as a tourist destination as well as a connection airport, sharing market risk on a wider customer portfolio. Traditional carriers are interested in less congested airports, where it is easier to find slot availability and to acquire new traffic to redirect towards their hub. This is the kind of relationship developed between Genoa Airport and Lufthansa Airlines, through its controlled regional carrier Air Dolomiti. Genoa Airport is connected by Air Dolomiti to Munich, Lufthansa's second hub, using small size vehicles with a high frequency (four connections per day).

The two charter carriers that operate at Genoa Airport (Air Italy and TUI Fly) account for only $3 \%$ of the total passenger traffic. They began to use Genoa Airport only recently (in the last 2-3 years) 


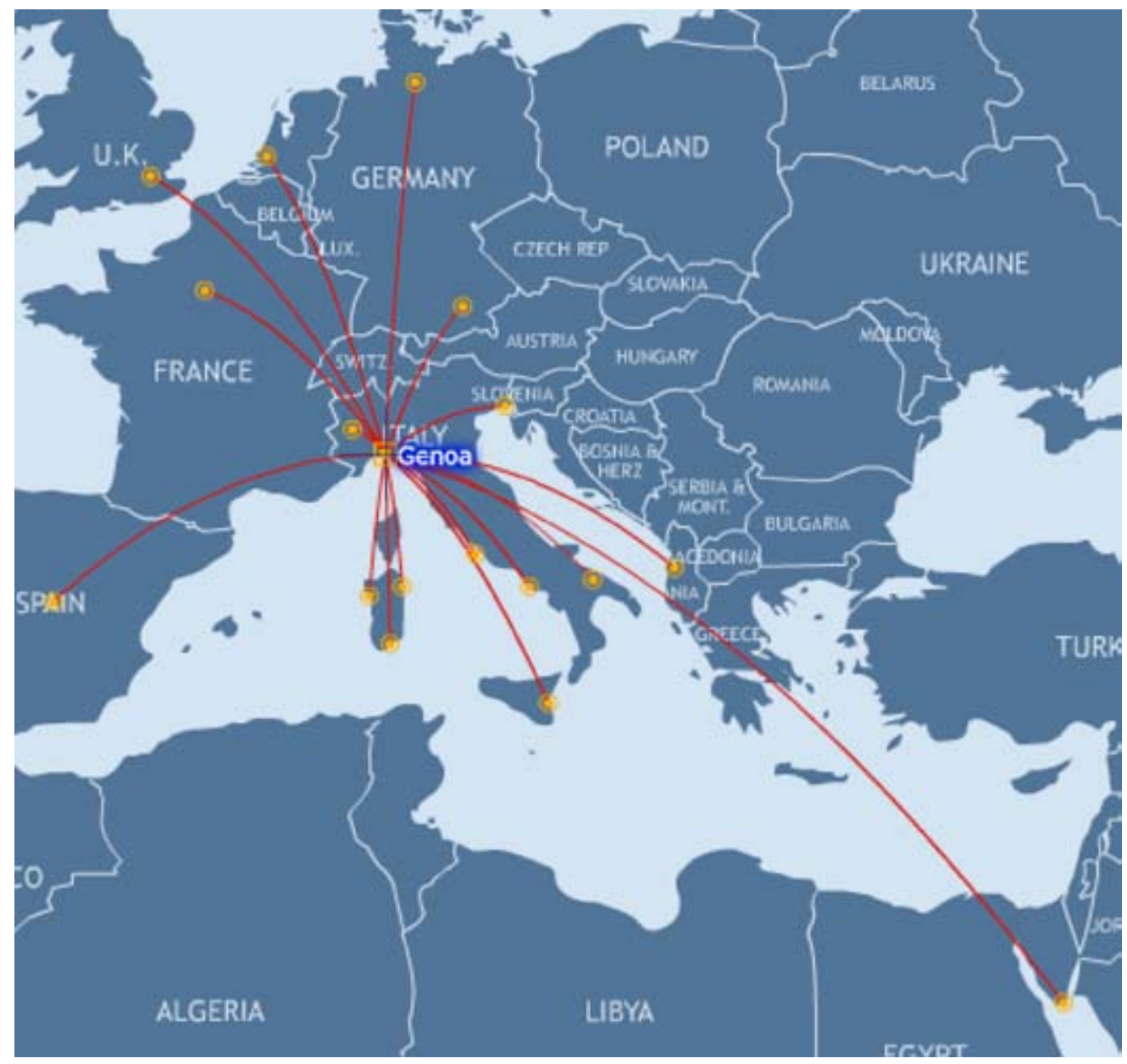

Figure 3: Genoa Airport route map. Source: www.rati.com.

Table 6: Genoa Airport-airline interaction drivers.

\begin{tabular}{lll}
\hline Interaction category & \multicolumn{1}{c}{ Airlines drivers } & \multicolumn{1}{c}{ Airports drivers } \\
\hline $\begin{array}{l}\text { Efficiency/ } \\
\text { operational } \\
\text { drivers }\end{array}$ & $\begin{array}{c}\text { Cost economies (better load factor), } \\
\text { market risk sharing (airport financial } \\
\text { support), higher service quality (higher } \\
\text { Market power/ }\end{array}$ & $\begin{array}{c}\text { Risk sharing (wider customers' } \\
\text { portfolio), higher service quality } \\
\text { (customised services like free }\end{array}$ \\
strategic drivers & $\begin{array}{c}\text { Create a feeding traffic to the hub } \\
\text { (Dolomiti airlines carries pax to Munich } \\
\text { palpensa hub), higher slots availability, }\end{array}$ & $\begin{array}{l}\text { Face neighbour airports competition } \\
\text { (higher pax traffic and improved }\end{array}$ \\
& $\begin{array}{l}\text { connectivity), increase bargaining } \\
\text { develop traffic in the basin of the airport } \\
\text { (co-terminalisation strategy) }\end{array}$ & $\begin{array}{l}\text { power (decreasing the dependence } \\
\text { from Alitalia), regional social } \\
\text { benefits (tourism development) }\end{array}$ \\
& &
\end{tabular}

Source: Our elaboration. 
and their traffic has strongly improved. With reference to these partners, totally dedicated to the leisure industry, the airport's non-economic objectives, like regional touristic development, acquire more relevance. In order to increase its attractiveness to outgoing charter networks, the airport management company has developed a co-terminalisation strategy with other Italian airports (e.g. Milan Malpensa) and has offered special conditions to passengers (e.g. free parking). The co-terminalisation strategy allows carriers to carry passengers originating from multiple points (in this case Genoa and Milan) to the same final destination on the same plane.

In this case, the airline's drivers seem to be the increased flight frequency and the achievement of a better load factor, while the airport's drivers are cost and risk sharing. Regarding incoming charter traffic, Genoa Airport may not rely on the strong touristic attractiveness of the region, so it has opted to exploit some niche markets, like the cruise industry, which has in Genoa's port the second Italian home port, and emerging markets like Russia and Scandinavia. Genoa Airport offers marketing incentives and facilities (dedicated lounge room) to tour operators to stimulate development of new routes.

Genoa Airport is at the moment working on a plan for the establishment of a Ryanair base. Ryanair requirements could not be matched by the only airport company: it needs the support and the involvement of the local public administration. The success of new LCC routes depends on a deep and widespread marketing plan involving public entities of destination and origin airports. Bureaucratic and legislative obstacles in addition to time lags in organising and defying public intervention hardly fit in with the strategy of LCCs, which tends to catch strategic windows and to exploit market opportunities for brief periods of time.

The four LCCs that operate at Genoa Airport (Ryanair, Belleair, Transavia and Blu-Express) account for $11.53 \%$ of the total passenger traffic. This type of interaction is particularly crucial for Genoa Airport, which has failed till now to establish a stable relationship with any LCC and has seen a dynamic opening and closing of air routes in the last 6-7 years. This trend has had an impact in terms of passenger rate volatility: for example, the LCC passenger rate has fluctuated in the last 2 years ranging from $12.52 \%$ in 2007 to $11.53 \%$ in 2008 . The main interaction problems are related to low bargaining power of the airport, imbalance in the incoming and outgoing passenger traffic, scarce number of repeating passengers, high load factor requirements and limited contractual obligations for LCCs.

\section{CONCLUSIONS}

In this paper, we have tried to explore vertical integration strategies between airports and airlines, with the aim of thoroughly understanding the interaction drivers. We have proposed a set of determinants distinguished by subject which can be broadly categorised into efficiency driven and market power driven (see Table 1) and then we have applied our assumptions in two case studies related to the Italian aviation industry.

The investigated cases, which involve different types of subjects (regional airports, traditional airlines as well as charter carriers and LCCs), have shown the validity of the proposed drivers (as Tables 5 and 6 show).

In particular, they seem to be not dependent on the different types of interaction, whereas they appear to be much more related to the characteristics of the partners involved in the relationship. In the case of regional airports, one of the most critical drivers is the creation of social benefits, whereas for LCCs efficiency drivers are prevailing (cost economies and risk sharing).

These preliminary conclusions require a deeper and more well-documented analysis in the future. In order to achieve stronger support, the research needs more empirical investigation through a wider number of case studies. 
Further research in this field should also be focused on the future environmental developments that could affect the risk rate and the competition level in the aviation industry, such as the 2008 financial crisis. IATA's latest data, in fact, outlines a strong passenger traffic drop ( $8 \%$ in the last 12 months). These environmental changes could, in fact, make vertical forms of interaction a strategic survival option for airports and airlines in order to maintain their competitive advantage.

\section{REFERENCES}

[1] Francis, G., Fidato, A. \& Humphreys, I., Airport-airline interaction: the impact of low-cost carriers on two European airports. Journal of Air Transport Management, 9(4), pp. 267-273, 2003. doi:10.1016/S0969-6997(03)00004-8

[2] International Center for Competitiveness Studies in the Aviation Industry (ICCSAI), Fact Book 2008. La Competitività del Trasporto Aereo in Europa, ICCSAI Editors: Bergamo, 2008.

[3] Cools, K. \& Roos, A., The Role of Alliances in Corporate Strategy, The Boston Consulting Group Report, 2005.

[4] Spekman, R.E., Forbes, T.M., Isabella, L.A. \& MacAvoy, T.C., Alliance management: a view from the past and a look to the future. Journal of Management Studies, 35(6), pp. 747-772, 1998. doi:10.1111/1467-6486.00118

[5] Lorange, P., Roos, J. \& Broon, P.S., Building successful strategic alliances. Long Range Planning, 25(6), pp. 10-17, 1992.

[6] Hamel, G., Competition for competence and inter-partner learning within international strategic alliances. Strategic Management Journal, 12, pp. 83-103, 1991. doi:10.1002/smj.4250120908

[7] Borys, B. \& Jemison, D.B., Hybrid arrangements as strategic alliances: theoretical issues and organizational combinations. Academy of Management Review, 14(2), pp. 234-249, 1989. doi:10.2307/258418

[8] Lei, D. \& Slocum, J.W., Global strategy, competence building and strategic alliances. California Management Review, 35(1), pp. 81-97, 1992.

[9] Rock, M.L. (ed), Fusioni e Acquisizioni. Aspetti Strategici, Finanziari e Organizzativi, McGraw-Hill: Milano, 1990.

[10] Garette, B. \& Dussauge, P., Alliances versus acquisitions: choosing the right option. European Management Journal, 18(1), pp. 63-69, 2000. doi:10.1016/S0263-2373(99)00069-9

[11] Goetsch, B. \& Albers, S., Towards a model of airport-airline interaction. German Aviation Research Society, www.garsonline.de, 2007.

[12] Franke, M., Innovation: the winning formula to regain profitability in aviation? Journal of Air Transport Management, 13(1), pp. 23-30, 2007. doi:10.1016/j.jairtraman.2006.11.003

[13] Graham, A., Managing Airports: An International Perspective, Butterworth Heinemann: Oxford, 2001.

[14] Klenk, M., New approaches in airline/airport relations: the charges framework of Frankfurt airport (Chapter 9). The Economic Regulation of Airports. Recent development in Australasia, North America and Europe, ed. P. Forsyth, Ashgate Editors: Berlin, pp. 125-139, 2004.

[15] Meersman, H., Van de Voorde, E. \& Vanelslander, T., The air transport sector after 2010: a modified market and ownership structure. European Journal of Transport and Infrastructure Research, 8(2), pp. 71-90, 2008.

[16] Auerbach, S. \& Koch, B., Cooperative approaches to managing air traffic efficiently - the airline perspective. Journal of Air Transport Management, 13(1), pp. 37-44, 2007. doi:10.1016/j. jairtraman.2006.10.005

[17] Albers, S., Koch, B. \& Ruff, C., Strategic alliances between airlines and airports - theoretical assessment and practical evidence. Journal of Air Transport Management, 11(2), pp. 48-58, 2005. doi:10.1016/j.jairtraman.2004.08.001 
[18] Koch, B., Opportunities and limitations to vertical alliance partnerships between airports and airlines. Proceedings of the 6th Conference on Applied Infrastructure Research, 2007.

[19] Oum, T.H. \& Fu, X., Impacts of airports on airlines competition: focus on airport performance and airport-airline vertical integration. Joint Research Transport Centre OECD, discussion paper 17, pp. 3-37, 2008.

[20] Humphreys, I., Ison, S. \& Francis, G., A review of the airport-low cost airline relationship. Review of Network Economics, 5(4), pp. 413-420, 2006. doi:10.2202/1446-9022.1105

[21] Seth, A., Sources of value creation in acquisitions: an empirical investigation. Strategic Management Journal, 11(6), pp. 431-446, 1990.

[22] Seth, A., Value creation in acquisitions: a re-examination of performance issues. Strategic Management Journal, 11(2), pp. 99-115, 1990. doi:10.1002/smj.4250110203

[23] Williamson, O.E., Economies as an antitrust defence: the welfare tradeoffs. American Economic Review, 58(1), pp. 18-36, 1968.

[24] Lewellen, W.G., A pure financial rationale for the conglomerate merger. Journal of Finance, 26(2), pp. 521-537, 1971. doi:10.2307/2326063

[25] Vicari, S., Nuove Dimensioni della Concorrenza. Strategie nei Mercati Senza Confini, Egea: Milano, 1989.

[26] Oum, T.H. \& Park, J.H., Airline alliances: current status, policy issues, and future directions. Journal of Air Transport Management, 3(3), pp. 133-144, 1997. doi:10.1016/S0969-6997(97)00021-5

[27] Iatrou, K., Oretti, M., Airline Choices for the Future: From Alliances to Mergers, Ashgate Publishing Ltd.: Hampshire, 2007.

[28] Clougherty, J.A., US domestic airline mergers: the neglected international determinants. International Journal of Industrial Organization, 20(4), pp. 557-576, 2002. doi:10.1016/ S0167-7187(00)00107-7

[29] Doganis, R., The Airline Business, 2nd edn, Routledge: London, 2006.

[30] Kim, E.H. \& Singal, V., Mergers and market power: evidence from the airline industry. American Economic Review, 83(3), pp. 549-569, 1993.

[31] Carney, M. \& Mew, K., Airport governance reform: a strategic management perspective. Journal of Air Transport Management, 9(4), pp. 221-232, 2003. doi:10.1016/S0969-6997(03)00003-6

[32] Serebrisky, T., Market power: airports, vertical integration between airports and airlines. Public Policy Journal, Note Number 259, 2003.

[33] Fuhr, J. \& Beckers, T., Vertical governance between airlines and airports - a transaction cost analysis. Review of Network Economics, 5(4), pp. 386-412, 2006. doi:10.2202/1446-9022.1104

[34] Kuchinke, B.A. \& Sickmann, J., The joint venture terminal 2 at Munich airport and its consequences: an analysis of competition economics. Proceedings of the 4th Conference on Applied Infrastructure Research, eds F. Fichert, J. Haucap \& K. Rommel, INFER Research Perspectives: Berlin, pp. 107-133, 2007.

[35] Malighetti, P., Martini, G. \& Paleari, S., An empirical investigation on the efficiency, capacity and ownership of Italian airports. Rivista di Politica Economica, 47(I-II), pp. 157-188, 2007.

[36] Sciandra, L., Aeroporti e Infrastrutture: Prospettive e Criticità del Quadro Regolatorio, Rapporto ISAE, Priorità nazionali. Infrastrutture materiali e immateriali, 2008.

[37] Assaeroporti, Analisi della Sostenibilità Economica e Proposte per lo Sviluppo la Mobilità, www. assaeroporti.it, 2006.

[38] SH\&E International Air Transport Consultancy, Capital Needs and Regulatory Oversight Arrangements. A Survey of European Airports. Aci Europe, 2006.

[39] Rosato, P., Proprietà e Governo dell'Impresa di Gestione Aeroportuale, Cacucci Editore: Bari, 2008. 